\title{
Mechanism of Calcium Transport Stimulated by Chlorothiazide in Mouse Distal Convoluted Tubule Cells
}

Frank A. Gesek and Peter A. Friedman

Department of Pharmacology and Toxicology, Dartmouth Medical School, Hanover, New Hampshire 03756

\begin{abstract}
Thiazide diuretics inhibit $\mathrm{Na}^{+}$and stimulate $\mathrm{Ca}^{2+}$ absorption in renal distal convoluted tubules. Experiments were performed on immortalized mouse distal convoluted tubule (MDCT) cells to determine the mechanism underlying the dissociation of sodium from calcium transport and the stimulation of calcium absorption induced by thiazide diuretics. Control rates of ${ }^{22} \mathrm{Na}^{+}$ uptake averaged $272 \pm 35 \mathrm{nmol} \mathrm{min}^{-1} \mathrm{mg}$ protein ${ }^{-1}$ and were inhibited $40 \%$ by chlorothiazide $\left(\mathrm{CTZ}, 10^{-4} \mathrm{M}\right)$. Control rates of ${ }^{36} \mathrm{Cl}^{-}$uptake averaged $340 \pm 50 \mathrm{nmol} \mathrm{min}^{-1} \mathrm{mg}$ protein ${ }^{-1}$ and were inhibited $50 \%$ by CTZ. CTZ stimulated ${ }^{45} \mathrm{Ca}^{2+}$ uptake by 45\% from resting levels of $2.86 \pm 0.26 \mathrm{nmol} \mathrm{min}^{-1} \mathrm{mg}$ protein ${ }^{-1}$. Bumetanide $\left(10^{-4} \mathrm{M}\right)$ had no effect on ${ }^{22} \mathrm{Na}^{+},{ }^{36} \mathrm{Cl}^{-}$, or ${ }^{45} \mathrm{Ca}^{2+}$ uptake. Control levels of intracellular calcium activity $\left(\left[\mathrm{Ca}^{2+}\right]_{i}\right)$ averaged $91 \pm 12 \mathrm{nM}$. CTZ elicited concentration-dependent increases of $\left[\mathrm{Ca}^{2+}\right]_{i}$ to a maximum of $654 \pm 31 \mathrm{nM}$ at $10^{-4} \mathrm{M}$. CTZ reduced intracellular chloride activity $\left(\left[\mathrm{Cl}^{-}\right]_{i}\right)$, as determined with the chloride-sensitive fluorescent dye 6-methoxy$\mathrm{N}$-(3-sulfopropyl)quinolinium. The chloride channel blocker 5-nitro-2-(3-phenylpropylamino)benzoic acid (NPPB, $10^{-5}$ $\mathrm{M})$ abolished the effect of $\mathrm{CTZ}$ on $\left[\mathrm{Cl}^{-}\right]_{i}$. NPPB also blocked CTZ-induced increases of ${ }^{45} \mathrm{Ca}^{2+}$. Resting membrane voltage, measured in cells loaded with the potential-sensitive dye $3,3^{\prime}$ dihexyloxacarbocyanine iodide $\left[\mathrm{DiOC}_{6}(3)\right]$, averaged $-72 \pm 2$ $\mathbf{m V}$. CTZ hyperpolarized cells in a concentration-dependent and reversible manner. At $10^{-4} \mathrm{M}, \mathrm{CTZ}$ hyperpolarized MDCT cells by $20.4 \pm 7.2 \mathrm{mV}$. Reduction of extracellular $\mathrm{Cl}^{-}$ or addition of NPPB abolished CTZ-induced hyperpolarization. Direct membrane hyperpolarization increased ${ }^{45} \mathrm{Ca}^{2+}$ uptake whereas depolarization inhibited ${ }^{45} \mathrm{Ca}^{2+}$ uptake. CTZ-stimulated ${ }^{45} \mathrm{Ca}^{2+}$ uptake was inhibited by the $\mathrm{Ca}^{2+}$ channel blocker nifedipine $\left(10^{-5} \mathrm{M}\right)$. We conclude that thiazide diuretics block cellular chloride entry mediated by apical membrane $\mathrm{NaCl}$ cotransport. Intracellular chloride, which under control conditions is above its equilibrium value, exits the cell through NPPB-sensitive chloride channels. This decrease of intracellular chloride hyperpolarizes MDCT cells and stimulates $\mathrm{Ca}^{2+}$ entry by apical membrane, dihydropyridine-sensitive $\mathrm{Ca}^{2+}$ channels. (J. Clin. Invest. 1992. 90:429-438.) Key
\end{abstract}

Portions of this work were presented at the annual meeting of the American Society of Nephrology, 17-20 November 1991, Baltimore, MD.

Address correspondence to Peter A. Friedman, Ph. D., Dept. of Pharmacology \& Toxicology, Dartmouth Medical School, 7650 Remsen, Hanover, NH 03756.

Received for publication 11 September 1991 and in revised form 21 February 1992

J. Clin. Invest.

(c) The American Society for Clinical Investigation, Inc.

$0021-9738 / 92 / 08 / 0429 / 10 \$ 2.00$

Volume 90, August 1992, 429-438 words: distal tubule • calcium transport • thiazide diuretics • intracellular calcium $\bullet \mathbf{N a C l}$ cotransport

\section{Introduction}

Despite the widespread therapeutic use of thiazide diuretics in the management of hypertension, congestive heart failure, and idiopathic hypercalciuria, the cellular mechanisms underlying their action on both sodium and calcium transport remain unclear. The unique ability of these agents to reduce renal calcium excretion, especially upon chronic administration, while simultaneously promoting that of sodium is a long-standing observation (1). Renal clearance (2), micropuncture (3-6), and microperfusion $(7,8)$ experiments identified the distal convoluted tubule as the nephron site at which thiazide diuretics inhibit sodium transport. Distal convoluted tubules are also the site at which thiazide diuretics stimulate calcium absorption (6). Uncertainty regarding the mechanism by which thiazide diuretics exert these opposing effects on cation transport may be attributable to the incomplete characterization of sodium and calcium absorption in this nephron segment.

Thiazide diuretics decrease distal nephron sodium and chloride absorption $(6,8)$ but enhance net calcium absorption (6). These effects require the presence of the drug in the tubular lumen $(9,10)$. The mechanism by which calcium transport is stimulated by thiazide diuretics is not known. It is generally accepted that thiazide diuretics do not alter transepithelial voltage (6). However, recent studies show that thiazide diuretics hyperpolarize plasma membrane voltage with little or no change of transepithelial voltage in homologous distal nephron structures of the amphibian nephron $(11,12)$, the flounder bladder (13), and in pilot studies, the rabbit distal convoluted tubule (14). Further, hydrochlorothiazide increases $\mathrm{Ca}^{2+}$ uptake across luminal membranes of distal convoluted tubule cells (15). We recently demonstrated that parathyroid hormone stimulates calcium entry in primary cell cultures of cortical thick ascending limb and distal convoluted tubule cells by activating dihydropyridine-sensitive calcium channels (16). Activation of such dihydropyridine-sensitive calcium channels in apical plasma membranes is consistent with the physiological effect of parathyroid hormone to increase the rate of transepithelial calcium transport $(17,18)$. Taken together, these observations suggested a plausible mechanism by which thiazide diuretics might stimulate calcium transport. Specifically, we theorized that inhibition of chloride entry by thiazide diuretics hyperpolarizes distal convoluted tubule cells, which in turn increases calcium entry. The experiments reported in the present work were undertaken to determine the mechanism of thiazide-induced hyperpolarization and to test this hypothesis using immortalized distal convoluted tubule cells. The results suggest that thiazide diuretics inhibit $\mathrm{NaCl}$ cotransport, resulting in diminished cellular chloride entry, decreased intracellular chloride, membrane hyperpolarization, and increased cal- 
cium entry. The increase of calcium entry is mediated by dihydropyridine-sensitive calcium channels.

\section{Methods}

Preparation and cell culture of immortalized distal convoluted tubule cells. Cortical thick ascending limb and distal convoluted tubule cells were isolated from mice (CD1; Charles River Breeding Laboratories Inc., Wilmington, MA) with a double-antibody procedure previously described (19) and established in primary cell culture. Antibiotics were removed $24 \mathrm{~h}$ before transformation. Cells were infected for $24 \mathrm{~h}$ with chimeric adenovirus 12-simian virus 40 (AD12/SV40; Dr. J. Rhim, National Cancer Institute). The use of this hybrid construct was employed previously to establish a collecting tubule cell line (20). After mock infectants had expired ( $10 \mathrm{~d})$, dishes of the infected cells were passaged. Preliminary screening was performed to monitor cAMP formation in response to PTH. Cells exhibiting PTH-induced cAMP accumulation $\geq 5 \times$ background were cloned by limiting cell dilution and grown to confluence. Determination of distal convoluted tubule phenotype was based upon the following criteria: $(a)$ inhibition of ${ }^{22} \mathrm{Na}^{+}$and ${ }^{36} \mathrm{Cl}^{-}$uptake by chlorothiazide $\left(10^{-4} \mathrm{M}\right) ;(b)$ absence of effect of bumetanide $\left(10^{-4} \mathrm{M}\right)$ on ${ }^{22} \mathrm{Na}^{+}$or ${ }^{36} \mathrm{Cl}^{-}$uptake; and $(c)$ stimulation of ${ }^{45} \mathrm{Ca}^{2+}$ uptake by chlorothiazide. Cells exhibiting these characteristics were established in culture and are designated mouse distal convoluted tubule (MDCT) ${ }^{1}$ cells. Cells were grown on $60-\mathrm{mm}$ dishes (Corning Glass Works, Corning Medical and Scientific, Corning, NY) in DME/ Ham's F12 media (DME Nutrient Mixture F-12 Ham; Sigma Chemical Co., St. Louis, MO) supplemented with $5 \%$ heat-inactivated $\left(56^{\circ} \mathrm{C}\right.$ for $20 \mathrm{~min}$ ) FCS (Sigma Chemical Co.) and PSN antibiotic mixture ( $50 \mu \mathrm{g}$ penicillin, $50 \mu \mathrm{g}$ streptomycin, $100 \mu \mathrm{g}$ neomycin $/ 100 \mathrm{ml}$ media; Gibco Laboratories, Gaithersburg, MD) in a humidified atmosphere of $95 \% \mathrm{O}_{2} / 5 \% \mathrm{CO}_{2}$ at $37^{\circ} \mathrm{C}$. Cell passages 5-21 were used in the present study.

Isotopic $\mathrm{Na}^{+}, \mathrm{Cl}^{-}$, and $\mathrm{Ca}^{2+}$ uptake measurements. A rapid filtration technique reported in previous investigations (21) was modified to measure uptake of ${ }^{22} \mathrm{Na}^{+},{ }^{36} \mathrm{Cl}^{-}$, and ${ }^{45} \mathrm{Ca}^{2+}$ by cultured cells. Cells (5-6 $\times 10^{6}$ cells $/ 60$-mm dish) were removed from dishes with $0.125 \%$ trypsin, $\leq 5 \mathrm{~min}$ (Sigma Chemical Co.) and rinsed with modified KRB containing (mM): $140 \mathrm{NaCl}, 5 \mathrm{KCl}, 1 \mathrm{CaCl}_{2}, 1 \mathrm{MgCl}_{2}$, buffered with 18 Tris base and 10 Hepes to $\mathrm{pH} 7.40 \pm 0.01$ and $295 \pm 1 \mathrm{mosmol} / \mathrm{kg}$ $\mathrm{H}_{2} \mathrm{O}$. To determine the effect of membrane voltage on ${ }^{45} \mathrm{Ca}^{2+}$ uptake, voltage was altered by varying extracellular $\mathrm{K}^{+}(0-100 \mathrm{mM})$, which was replaced isosmotically with $\mathrm{Na}^{+}$and clamped by use of the ionophore valinomycin $\left(10^{-6} \mathrm{M}\right)$. The chloride dependence of ${ }^{45} \mathrm{Ca}^{2+}$ uptake was evaluated by isosmotically replacing $\mathrm{Cl}^{-}$with gluconate. For these experiments, calcium activity of the gluconate-containing solutions was measured with a calcium-specific electrode (model 932000; Orion Research Inc., Cambridge, MA) and adjusted by addition of $\mathrm{CaCl}_{2}$ to be identical to that of chloride-containing solutions at $\mathrm{pH} 7.4$.

Buffer, with or without further additions, (total volume $=100 \mu \mathrm{l}$ ) was placed in $12 \times 75 \mathrm{~mm}$ polystyrene tubes and a $50-\mu 1$ aliquot of cells was added for $1 \mathrm{~min}$ before addition and vortexing of a $50-\mu \mathrm{l}$ aliquot of ${ }^{22} \mathrm{Na}^{+}(10 \mu \mathrm{Ci} / \mathrm{ml}$, carrier-free; Amersham Corp., Arlington Heights, IL), ${ }^{36} \mathrm{Cl}^{-}(58 \mu \mathrm{Ci} / \mathrm{ml}$; ICN Radiochemicals, Costa Mesa, CA) or ${ }^{45} \mathrm{Ca}^{2+}(1 \mu \mathrm{Ci} / \mathrm{ml}$, carrier-free; New England Nuclear, Boston, MA ) to initiate isotope uptake. All sample tubes were maintained at $37^{\circ} \mathrm{C}$ in a shaking incubator. Control experiments indicated that tracer uptake was linear for $2 \mathrm{~min}$. In all experiments reported, tracer uptake was terminated after $1 \mathrm{~min}$ by rapid addition of ice-cold isosmotic, $\mathrm{LiCl}-$ Hepes rinse buffer (140 mM LiCl, $10 \mathrm{mM}$ Hepes; pH 7.40, 295 \pm 2

1. Abbreviations used in this paper: $\left[\mathrm{Ca}^{2+}\right]_{\mathrm{i}}$, intracellular calcium activity; $\mathrm{DiOC}_{6}(3), 3,3$ 'dihexyloxacarbocyanine iodide; MDCT, mouse distal convoluted tubules; NPPB, 5-nitro-2(3-phenylpropylamino) benzoic acid; SPQ, 6-methoxy- $N$-( 3-sulfopropyl)quinolinium. mosmol/ $\mathrm{kg} \mathrm{H}_{2} \mathrm{O}$ ) and filtered onto Whatman GF/C filters (Whatman Inc., Clifton, NJ) using a 12-port manifold (Millipore Continental Water Systems, Bedford, MA) followed by two additional rinses with $\mathrm{LiCl}-\mathrm{Hepes}$ buffer. For experiments in which $\mathrm{Cl}^{-}$was replaced, an isosmotic $\mathrm{Li}_{2} \mathrm{SO}_{4}$-Hepes buffer ( $140 \mathrm{mM} \mathrm{Li}_{2} \mathrm{SO}_{4}, 10 \mathrm{mM}$ Hepes; $\mathrm{pH}$ $7.40,295 \pm 2 \mathrm{mosmol} / \mathrm{kg} \mathrm{H}_{2} \mathrm{O}$ ) was used for rinses.

Filters containing cells in which ${ }^{22} \mathrm{Na}^{+}$was measured were counted in a Beckman 8000 gamma counter (Beckman Instruments Inc., Fullerton, CA). Filters containing cells for uptake of ${ }^{36} \mathrm{Cl}^{-}$or ${ }^{45} \mathrm{Ca}^{2+}$ were placed in vials containing $10 \mathrm{ml}$ of Aquasol 2 (New England Nuclear). Radioactivity was determined by scintillation counting with a Beckman LS3801 counter (Beckman Instruments Inc.). Nonspecific binding of ${ }^{22} \mathrm{Na}^{+},{ }^{36} \mathrm{Cl}^{-}$, or ${ }^{45} \mathrm{Ca}^{2+}$ to filters and cells was determined in the presence of $\mathrm{LiCl}-\mathrm{Hepes}$ (or $\mathrm{Li}_{2} \mathrm{SO}_{4}-\mathrm{Hepes}$ ) buffer and subtracted to calculate uptake. Protein content was measured by the method of Lowry et al. (22) on 50- $\mu$ l aliquots of cells. Tracer uptakes are expressed as nanomoles per minute $\cdot \mathrm{mg}$ protein $\left(\mathrm{nmol} \mathrm{min}^{-1} \mathrm{mg}\right.$ protein $\left.^{-1}\right)$.

Measurement of intracellular $\mathrm{Ca}^{2+}$ activity $\left(\left[\mathrm{Ca}^{2+}\right]_{i}\right)$. Cells were grown to near confluence on $25-\mathrm{mm}$ glass coverslips $(\sim 3 \mathrm{~d})$. Cells on coverslips were rinsed three times with $\mathrm{KRB}$ and incubated with $10^{-5}$ M fura-2 AM (Molecular Probes, Inc., Eugene, OR) in $2.5 \mathrm{ml} \mathrm{KRB}$ for $60 \mathrm{~min}$ at $37^{\circ} \mathrm{C}$ on a rotating incubator. The coverslips were rinsed twice with KRB to remove extracellular fura- $2 \mathrm{AM}$ and mounted in a chamber of a microincubation system, temperature-controlled to $37^{\circ} \mathrm{C}$ (MS-C; Narishige USA, Inc., Greenvale, NY). The chamber was affixed to the stage of a Nikon Diaphot inverted microscope (Nikon Inc., Melville, NY). Fluorescence excitation and emission intensity were measured with a Nikon Photoscan-2 (Nikon Inc.). Interference filters of $340 \mathrm{~nm}$ and $380 \mathrm{~nm}$ (Omega Optical Inc., Brattleboro, VT) were employed for fluorescence excitation. Emission at $510 \mathrm{~nm}$ was followed by using a $510 \mathrm{~nm}$ dichroic mirror (DM510; Nikon Inc.) in series with a $510 \pm 5 \mathrm{~nm}$ interference filter (Omega Optical Inc.). Fields of two to three cells on the cover slip were selected by using a shutter assembly mounted in front of the photomultiplier tube. An area devoid of cells on the coverslip or a coverslip of cells not incubated with fura-2 AM was used to measure and subtract background autofluorescence in each experiment. Background was typically observed to be $<5 \%$ of fluorescence of cells loaded with fura-2. Before administration of chlorothiazide, a baseline recording of $\left[\mathrm{Ca}^{2+}\right]_{i}$ was obtained. Fluorescence intensity was sampled at a rate of 2 points/s. Absolute values of $\left[\mathrm{Ca}^{2+}\right]_{i}$ were based on calibrations that were performed as described previously (16). $\left[\mathrm{Ca}^{2+}\right]_{i}$ was calculated using the equation derived by Grynkieiwcz et al. (23).

Membrane voltage. Fluorescence measurements of membrane potential were performed with distal convoluted tubule cells grown on coverslips and loaded with the voltage-sensitive probe 3,3'dihexyloxacarbocyanine iodide $\left(\mathrm{DiOC}_{6}(3)\right.$; Molecular Probes, Inc.). A $10-\mathrm{mM}$ stock of $\mathrm{DiOC}_{6}(3)$ in DMSO was prepared and filtered through a $0.45-\mu \mathrm{m}$ Ultrafree-MC cartridge (Millipore Continental Water Systems). Cells on coverslips were prepared and incubated with $10^{-6} \mathrm{M} \mathrm{DiOC}_{6}$ (3) for $60 \mathrm{~min}$ in a similar manner to those incubated with fura-2 AM described above. An excitation wavelength of $490 \mathrm{~nm}$ and emission wavelength of $510 \mathrm{~nm}$ were used. Fluorescence intensity was sampled at a rate of 1 point $/ \mathrm{s}$. Alterations in membrane voltage are presented as relative changes of $\mathrm{DiOC}_{6}(3)$ fluorescence. Calibrations were performed by a null-point procedure using graded changes in external potassium in the presence of valinomycin (24).

Intracellular chloride activity. Intracellular chloride $\left(\left[\mathrm{Cl}^{-}\right]_{i}\right)$ was measured in MDCT cells grown on glass coverslips by using the $\mathrm{Cl}^{-}$sensitive dye 6-methoxy- $N$-(3-sulfopropyl)quinolinium (SPQ; Molecular Probes, Inc.). A 50-mM stock solution of SPQ in DMSO was prepared. Loading solutions consisted of $5 \mathrm{mM} \mathrm{SPQ} \mathrm{in} \mathrm{KRB.} \mathrm{Loading}$ of cells with SPQ was accomplished by preincubating the cells for $5 \mathrm{~h}$ at $37^{\circ} \mathrm{C}$. After rinsing, the coverslip was inserted into the microincubation chamber described above. Fluorescence intensity was quantified with a Nikon Photoscan-2 (Nikon Inc.). Excitation and emission interference filters (Omega Optical Inc.) of $340 \mathrm{~nm}$ and $450 \mathrm{~nm}$, respec- 
tively, were employed. Fluorescence intensity was sampled at a rate of 1 point/s. At the end of each experiment $150 \mathrm{mM}$ potassium thiocyanate $+10^{-5} \mathrm{M}$ valinomycin was added to quench intracellular fluorescence (25). SPQ leakage was estimated to be $\sim 12 \% / \mathrm{h}$. Alterations in intracellular chloride are presented as relative changes in SPQ fluorescence.

Preparation of drug solutions and statistical evaluation. Chlorothiazide and bumetanide (a gift from Hoffmann-LaRoche, Nutley, NJ) were prepared so that the molar concentration indicated in the text was the final concentration to which cells were exposed. Solutions containing drugs were prepared fresh daily. Chemicals were of the highest grade commercially available. All ${ }^{22} \mathrm{Na}^{+},{ }^{36} \mathrm{Cl}^{-}$, and ${ }^{45} \mathrm{Ca}^{2+}$ uptake measurements within an experiment were performed in triplicate. The data are presented as mean $\pm \mathrm{SE}$, where $n$ indicates the number of separate experiments. Intracellular calcium, $\left(\left[\mathrm{Ca}^{2+}\right]_{\mathrm{i}}\right)$, intracellular chloride activity, and membrane voltage were measured in duplicate or triplicate within a single experiment and reported as the mean $\pm S E$ of $n$ separate experiments. Comparisons between control and drug treatment groups were examined by post hoc analysis of multiple comparisons with Newman-Keuls tests using the statistical software ANCOM (SciLab, Guilderland, NY). Values of $P \leq 0.05$ were assumed to be significant.

\section{Results}

Diuretic effects on ${ }^{22} \mathrm{Na}^{+}$and ${ }^{36} \mathrm{Cl}^{-}$uptake by cultured $\mathrm{MDCT}$ cells. Isolation of cells from mouse kidney cortex using the double-antibody procedure based on the nephron localization of the Tamm-Horsfall antigen yields both cortical thick ascending limb and distal convoluted tubule cells (19). Since mouse $(26,27)$ and human (28) cortical thick ascending limb and distal convoluted tubule cells possess PTH receptors, the distinguishing feature between these cell types is their unique $\mathrm{Na}^{+}$ transport characteristics. Apical membrane $\mathrm{Na}^{+}$entry in cortical thick ascending limbs is mediated by $\mathrm{Na}: \mathrm{K}: 2 \mathrm{Cl}$ cotransport and is inhibitable by sulfamoyl loop diuretics such as bumetanide or furosemide (29-31). Sodium influx across luminal membranes of distal convoluted tubules is thought to be mediated by potassium-independent $\mathrm{NaCl}$ cotransport $(8,32,33)$ that is selectively inhibited by thiazide diuretics. This distinct pattern of sensitivity to bumetanide or thiazide diuretics allows discrimination between cortical thick ascending limb and distal convoluted tubule phenotypes.

The effects of the thiazide diuretic, chlorothiazide, and the loop diuretic bumetanide on sodium and chloride uptake by MDCT cells are depicted in Fig. 1. At an extracellular $\mathrm{NaCl}$ concentration of $140 \mathrm{mM}$, and in the absence of $\mathrm{CO}_{2}$ and bicarbonate, chlorothiazide $\left(10^{-4} \mathrm{M}\right)$ inhibited ${ }^{22} \mathrm{Na}^{+}$uptake by $40 \pm 5 \%$ from $272 \pm 35$ to $163 \pm 29 \mathrm{nmol} \mathrm{min}^{-1} \mathrm{mg} \operatorname{protein}^{-1}(P$ $<0.05$ ) and ${ }^{36} \mathrm{Cl}^{-}$uptake by $50 \pm 5 \%$ from $340 \pm 50$ to $172 \pm 37$ nmol $\min ^{-1} \mathrm{mg}$ protein ${ }^{-1}(P<0.01)$. In contrast, the same concentration of bumetanide had no demonstrable effect on either ${ }^{22} \mathrm{Na}^{+}$or ${ }^{36} \mathrm{Cl}^{-}$uptake. Inhibition of $\mathrm{Na}^{+}$and $\mathrm{Cl}^{-}$transport by chlorothiazide, coupled with lack of effect of bumetanide, strongly support the view that MDCT cells express a distal convoluted tubule phenotype. Similar rates of ${ }^{22} \mathrm{Na}^{+}$uptake were noted in the absence of external potassium (data not shown). These observations are consistent with the view that $\mathrm{NaCl}$ cotransport is responsible for a major component of $\mathrm{Na}^{+}$ uptake in these immortalized distal convoluted tubule cells and that chlorothiazide blocks $\mathrm{Cl}^{-}$entry by inhibiting $\mathrm{NaCl}$ cotransport.

Chlorothiazide-induced decreases of intracellular chloride. The aforementioned results are compatible with the hypothesis

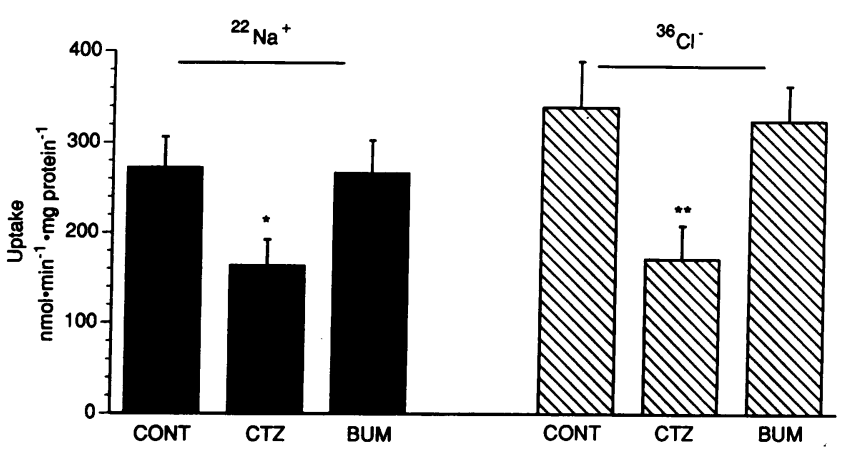

Figure 1. Effects of chlorothiazide $\left(C T Z, 10^{-4} \mathrm{M}\right)$ and bumetanide ( $B U M, 10^{-4} \mathrm{M}$ ) on ${ }^{22} \mathrm{Na}^{+}$and ${ }^{36} \mathrm{Cl}^{-}$uptake by MDCT cells. Bars are mean $\pm \mathrm{SE}$ of triplicate measurements in $n=5$ separate experiments. ${ }^{*} P<0.05,{ }^{* *} P<0.01$ compared with control $(C O N T)$.

that by blocking chloride entry chlorothiazide decreases intracellular chloride. To test this directly, we monitored intracellular chloride activity with the chloride-sensitive fluorescent dye, SPQ. SPQ fluorescence is quenched by chloride and by other halide ions (34). Decreases of fluorescence intensity are inversely related to intracellular chloride activity $(25,34)$. The results of a representative experiment in which SPQ fluorescence was measured in response to chlorothiazide are depicted in Fig. 2. In this experiment, blocking $\mathrm{Cl}^{-}$entry with chlorothiazide reduced intracellular chloride activity. When chlorothiazide was washed out of the bathing solution, intracellular chloride returned to control levels. Application of the chloride channel blocker 5-nitro-2-(3-phenylpropylamino)benzoic acid (NPPB) resulted in a profound elevation of intracellular chloride. In the presence of NPPB, chlorothiazide had no detectable effect on intracellular chloride activity. The effect of NPPB was fully reversible upon exchanging the bath for one devoid of drugs. A second application of chlorothiazide elicited a similar fall of intracellular chloride and, again, was reversible upon removal of the drug. Finally, application of potassium thiocyanate $(+$ valinomycin) resulted in virtually complete quenching of intracellular SPQ fluorescence. These results indicate that inhibiting chloride entry with chlorothiazide reduced intracellular chloride activity and blocking chloride exit increased intracellular chloride activity. These observations are consistent with the view that MDCT cells express plasma membrane chloride channels that mediate cellular chloride efflux.

Effects of chlorothiazide on ${ }^{45} \mathrm{Ca}^{2+}$ uptake and $\left[\mathrm{Ca}^{2+}\right]_{i}$. Although renal $\mathrm{Ca}^{2+}$ and $\mathrm{Na}^{+}$absorption normally proceed in parallel, thiazide diuretics dissociate $\mathrm{Na}^{+}$from $\mathrm{Ca}^{2+}$ movement by inhibiting sodium transport and enhancing calcium absorption in distal convoluted tubules (6). Lajeunesse et al. (15) demonstrated that the hypocalciuric effect of thiazide diuretics is due to increased $\mathrm{Ca}^{2+}$ uptake across luminal membranes of distal convoluted tubule cells. To determine if thiazide diuretics promote $\mathrm{Ca}^{2+}$ transport in MDCT cells we measured ${ }^{45} \mathrm{Ca}^{2+}$ uptake and $\left[\mathrm{Ca}^{2+}\right]_{i}$ in these cells. The results. illustrated in Fig. 3 demonstrate that chlorothiazide increased ${ }^{45} \mathrm{Ca}^{2+}$ uptake by $45 \pm 4 \%$ from $2.86 \pm 0.26$ to $4.15 \pm 0.25 \mathrm{nmol}$ $\mathrm{min}^{-1} \mathrm{mg}$ protein ${ }^{-1}(P<0.01)$. Bumetanide had no detectable effect on ${ }^{45} \mathrm{Ca}^{2+}$ uptake. The results of experiments in which the effect of chlorothiazide on $\left[\mathrm{Ca}^{2+}\right]_{i}$ was measured are shown in Figs. 4 and 5. Basal $\left[\mathrm{Ca}^{2+}\right]_{\mathrm{i}}$ averaged $91 \pm 12 \mathrm{nM}$. Composite 


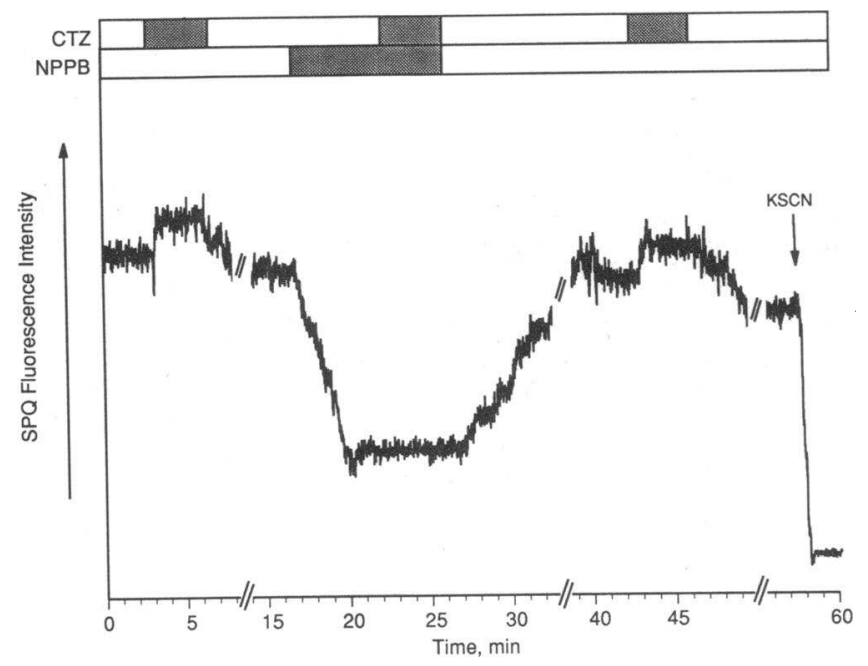

Figure 2. Representative recording of changes of intracellular $\mathrm{Cl}^{-}$ measured in two to three cells grown on coverslips and loaded with the fluorescent indicator, 6-methoxy- $N$-(3-sulfopropyl)-quinolinium $(S P Q)$. Decreases of fluorescence intensity are inversely related to intracellular chloride activity. Addition of drug is indicated by the shaded region of the bar above the recording. Chlorothiazide (CTZ, $10^{-4} \mathrm{M}$ ) rapidly decreased intracellular $\mathrm{Cl}^{-}$. After a 10 -min exchange of the bathing solution containing CTZ for one devoid of drug, intracellular $\mathrm{Cl}^{-}$returned to control levels. Application of the $\mathrm{Cl}^{-}$-channel blocker 5-nitro-2 (3-phenylpropylamino) benzoic acid (NPPB, 10 $0^{-5}$ $\mathrm{M}$ ) increased intracellular $\mathrm{Cl}^{-}$. A second application of CTZ in the presence of NPPB blocked the decrease of intracellular $\mathrm{Cl}^{-}$. Upon exchange of the extracellular bath for one devoid of CTZ and NPPB, intracellular $\mathrm{Cl}^{-}$returned to control levels. A third application of CTZ resulted in a reversible fall of intracellular chloride comparable in magnitude to that observed on the first application. Cells were rinsed and potassium thiocyanate $\left(K S C N, 15010^{-3} \mathrm{M}\right)+510^{-6} \mathrm{M}$ valinomycin was added to quench intracellular SPQ fluorescence (25). Comparable results were obtained in three additional experiments.

dose-response relations between chlorothiazide and $\left[\mathrm{Ca}^{2+}\right]_{i}$ are presented in Fig. 5. Chlorothiazide elicited concentrationdependent increases of $\left[\mathrm{Ca}^{2+}\right]_{i}$ that occurred with successive additions of the drug. Maximal increases to $654 \pm 31 \mathrm{nM}$ were

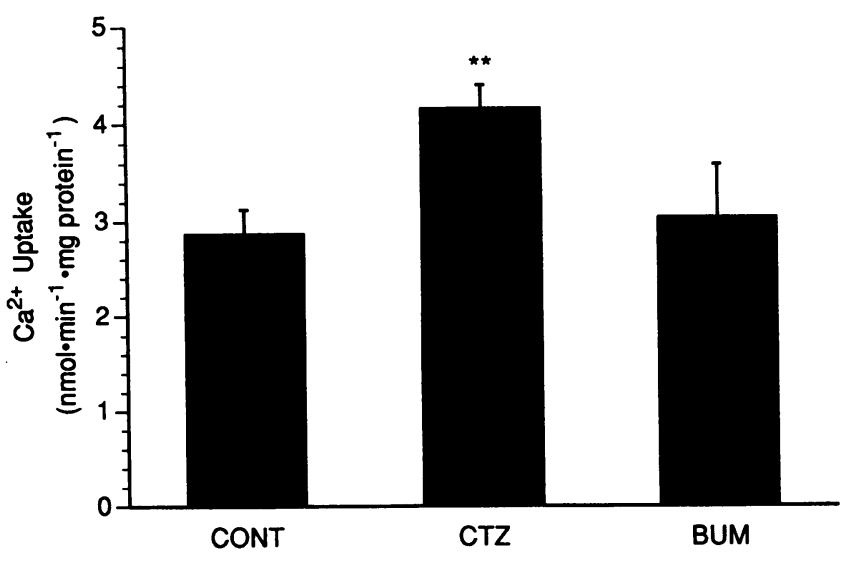

Figure 3. Effects of chlorothiazide $\left(C T Z, 10^{-4} \mathrm{M}\right)$ and bumetanide ( $B U M, 10^{-4} \mathrm{M}$ ) on ${ }^{45} \mathrm{Ca}^{2+}$ uptake by MDCT cells. Bars represent the mean $\pm \mathrm{SE}$ of triplicate measurements in $n=5$ separate experiments. ${ }^{* *} P<0.01$.

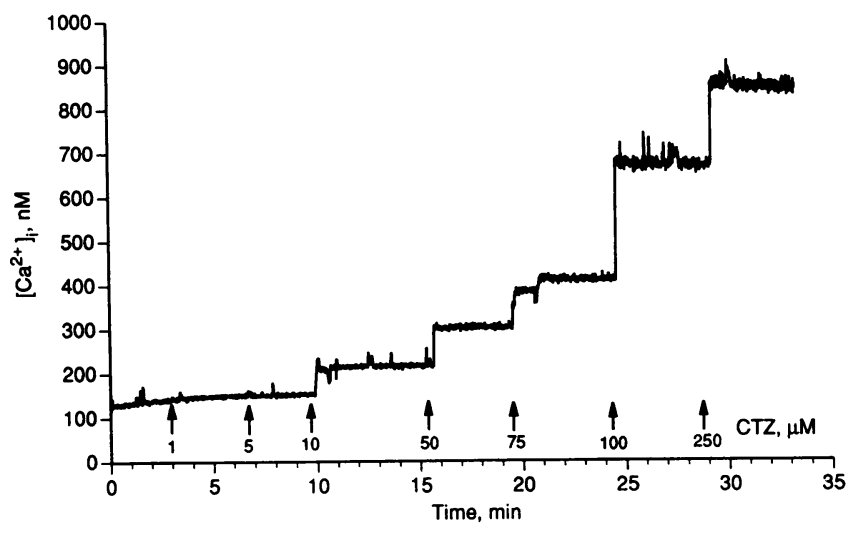

Figure 4. Chlorothiazide-induced elevations of intracellular calcium $\left(\left[\mathrm{Ca}^{2+}\right]_{i}\right)$ in MDCT cells. Recording shows the results of a representative experiment in which increasing concentrations of chlorothiazide (CTZ; $1-250 \mu \mathrm{M}$ ) were added to cells grown on coverslips and loaded with the fluorescent indicator, fura-2 AM. CTZ concentrations $\geq 10 \mu \mathrm{M}$ caused immediate increases of $\left[\mathrm{Ca}^{2+}\right]_{i}$. These results are typical of a total of seven determinations.

achieved with $10^{-4} \mathrm{M}$ chlorothiazide. The response appears to be biphasic: at concentrations below $5010^{-6} \mathrm{M}$ chlorothiazide increased $\left[\mathrm{Ca}^{2+}\right]_{\mathrm{i}}$ in a sigmoidal fashion but a sharp increase of $\left[\mathrm{Ca}^{2+}\right]_{\mathrm{i}}$ was noted at 75 and $10010^{-6} \mathrm{M}$. The origin of this biphasic pattern, is uncertain.

Hyperpolarization of membrane voltage by chlorothiazide. Thiazide diuretics hyperpolarize basolateral membranes of amphibian distal tubule cells $(11,12)$ and flounder urinary bladder cells (13). Moreover, in those studies, hyperpolarization of basolateral membrane voltage was accompanied by parallel decreases of intracellular $\mathrm{Cl}^{-}$activity. The results shown in Figs. 1 and 2 and Table I are compatible with the hypothesis that the

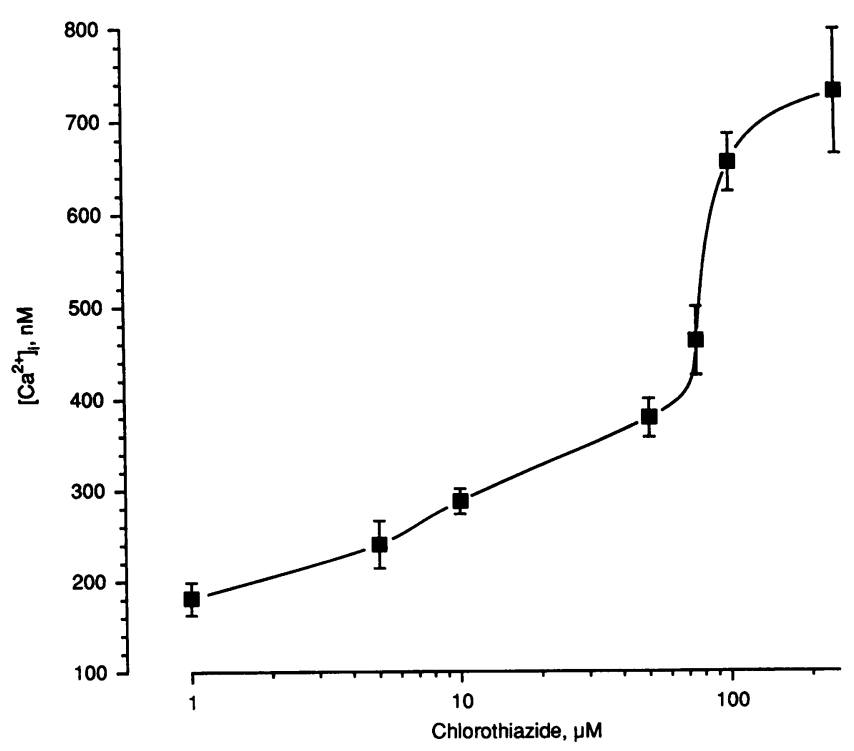

Figure 5. Dose-response relations of chlorothiazide on intracellular calcium $\left(\left[\mathrm{Ca}^{2+}\right]_{i}\right)$ in MDCT cells grown on coverslips and loaded with fura-2 AM. Addition of chlorothiazide resulted in dose-dependent increases of $\left[\mathrm{Ca}^{2+}\right]_{i}$. Each point represents the mean $\pm \mathrm{SE}$ of seven independent experiments. 
Table I. Effect of Chloride Replacement on Chlorothiazidestimulated ${ }^{45} \mathrm{Ca}^{2+}$ Uptake

\begin{tabular}{rccc}
\hline Chloride & Valinomycin & Chlorothiazide & ${ }^{45} \mathrm{Ca}^{2+}$ uptake \\
\hline$m M$ & & & $n$ mol min $^{-1}$ mg protein \\
& & - & $2.19 \pm 0.30$ \\
0 & - & + & $2.24 \pm 0.20$ \\
0 & - & - & $2.25 \pm 0.22$ \\
0 & + & + & $2.17 \pm 0.23$ \\
0 & + & - & $2.41 \pm 0.28$ \\
140 & + & + & $2.43 \pm 0.30$ \\
140 & + & &
\end{tabular}

${ }^{45} \mathrm{Ca}^{2+}$ uptake was measured as described in Methods. Isosmotic chloride replacement was achieved with gluconate. The final concentration of valinomycin was $10^{-5} \mathrm{M}$ and chlorothiazide was $10^{-4} \mathrm{M}$. Values represent mean $\pm \mathrm{SE}$ of triplicate measurements performed in three separate experiments.

hyperpolarization induced by chlorothiazide in MDCT cells resulted from inhibition of luminal membrane $\mathrm{NaCl}$ cotransport with an attendant decrease of intracellular $\mathrm{Cl}^{-}$. To determine if thiazide diuretics affect membrane voltage in MDCT cells, voltage was measured with the fluorescent probe $\mathrm{DiOC}_{6}(3)$. In the experiment depicted in Fig. 6, we followed membrane voltage as a function of time in MDCT cells grown on glass coverslips. Reductions in fluorescence correspond to hyperpolarization of membrane voltage. Chlorothiazide $\left(10^{-4}\right.$

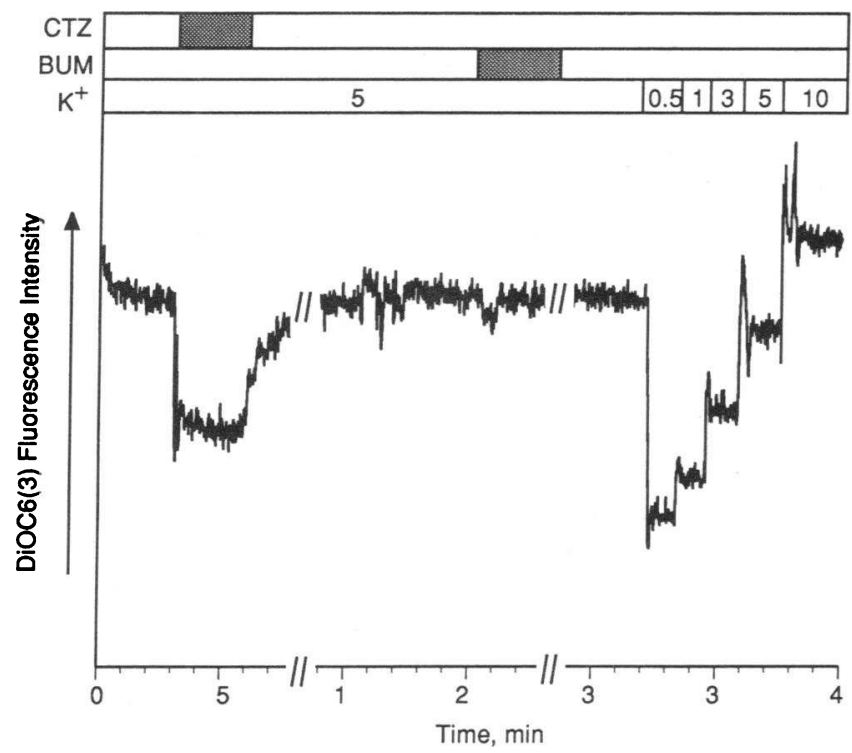

Figure 6. Effects of chlorothiazide $\left(C T Z, 10^{-4} \mathrm{M}\right)$ and bumetanide $\left(B U M, 10^{-4} \mathrm{M}\right)$ on membrane voltage in MDCT cells. Changes in membrane potential were measured in cells grown on coverslips and loaded with the fluorescent indicator, 3,3'-dihexyloxacarbocyanine $\left[\mathrm{DiOC}_{6}(3)\right]$. Decreases of fluorescence intensity are inversely related to membrane voltage. CTZ caused a rapid hyperpolarization that was completely reversed upon washout of the drug. BUM had no notable effect on $\mathrm{DiOC}_{6}(3)$ fluorescence. A null-point calibration, performed at the end of each experiment with graded concentrations of external $\mathrm{K}^{+}$in the presence of $10^{-6} \mathrm{M}$ valinomycin, is shown at the right-hand portion of the recording. Similar observations were made in a total of five experiments.
M) decreased fluorescence by $\sim 30 \%$. Upon exchanging the extracellular bathing solution for one devoid of the drug, fluorescence intensity returned to control levels. In contrast to the hyperpolarization elicited by chlorothiazide, bumetanide $\left(10^{-4} \mathrm{M}\right)$ had no detectable effect on membrane voltage. As shown in the right-hand portion of the recording, changes in $\mathrm{DiOC}_{6}(3)$ fluorescence were calibrated with graded concentrations of extracellular potassium in the presence of the potassium ionophore valinomycin (24). Resting membrane voltage was calculated from the average null-point value for extracellular potassium $(8.13 \pm 0.60 \mathrm{mM}, n=8)$ and the measured intracellular potassium ( $119 \pm 9 \mathrm{mM}, n=5)$ and averaged $-72 \pm 2$ $\mathrm{mV}(n=8)$. Fig. 7 shows that chlorothiazide elicited stepwise decreases in fluorescence with incremental concentrations of the drug. Detectable changes in fluorescence were noted with concentrations of chlorothiazide as low as $10^{-6} \mathrm{M}$. Maximal decreases of fluorescence intensity of $35 \pm 13 \%$ were achieved at chlorothiazide concentrations of $\sim 1 \times 10^{-4}$ to $2.5 \times 10^{-4} \mathrm{M}$. Again, chlorothiazide-induced hyperpolarization was rapidly and completely reversible upon removal of the drug. This observation indicates that the reduction in fluorescence was not due to either some toxic action of the drug or diffusion of the dye. The average maximal reduction of fluorescence corresponds to a hyperpolarization of $20.4 \pm 7.2 \mathrm{mV}(n=5)$. These results demonstrate that chlorothiazide hyperpolarizes mammalian distal convoluted tubule cells.

To determine if alterations of membrane voltage directly influence $\mathrm{Ca}^{2+}$ influx, MDCT cells were hyperpolarized or depolarized by varying the extracellular potassium concentration in the presence of valinomycin $\left(10^{-5} \mathrm{M}\right)$. Fig. 8 shows that ${ }^{45} \mathrm{Ca}^{2+}$ uptake increased when cells were hyperpolarized. Conversely, ${ }^{45} \mathrm{Ca}^{2+}$ uptake decreased when cells were depolarized. As shown in the inset to Fig. 8, independent experiments demonstrate that these alterations in $\mathrm{K}^{+}$elicited linear Nernstian responses of $\mathrm{DiOC}_{6}(3)$ fluorescence and the appropriate changes in membrane voltage. These results support the view

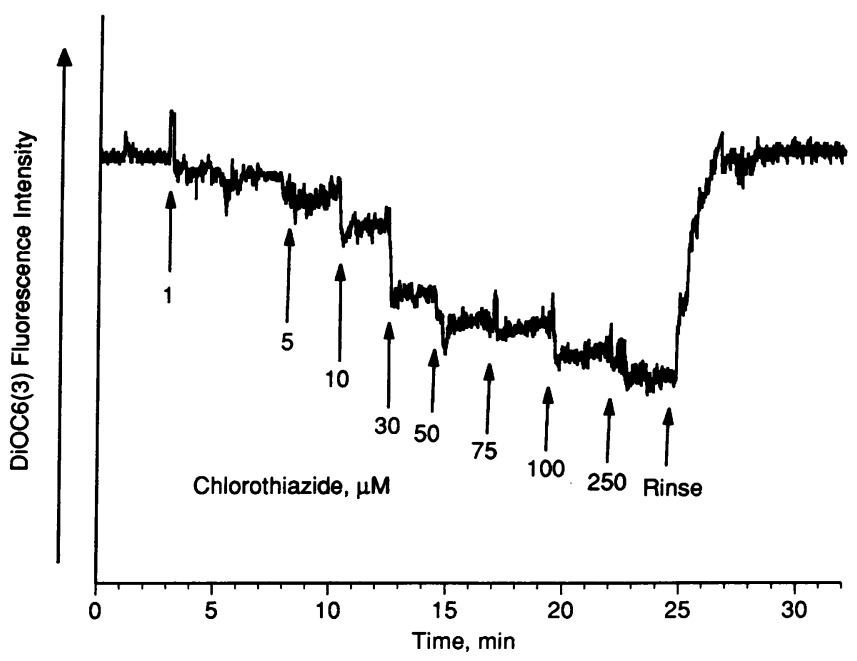

Figure 7. Concentration dependence of chlorothiazide-induced cellular hyperpolarization. Alterations in membrane voltage were measured with $\mathrm{DiOC}_{6}(3)$ as described in Methods. The recording shows that upon addition of graded concentrations of chlorothiazide (1-250 $\mu \mathrm{M})$, dose-dependent decreases of fluorescence intensity were observed. Upon washout of CTZ, membrane voltage returned to control levels. Comparable results were obtained in a total of five experiments. 


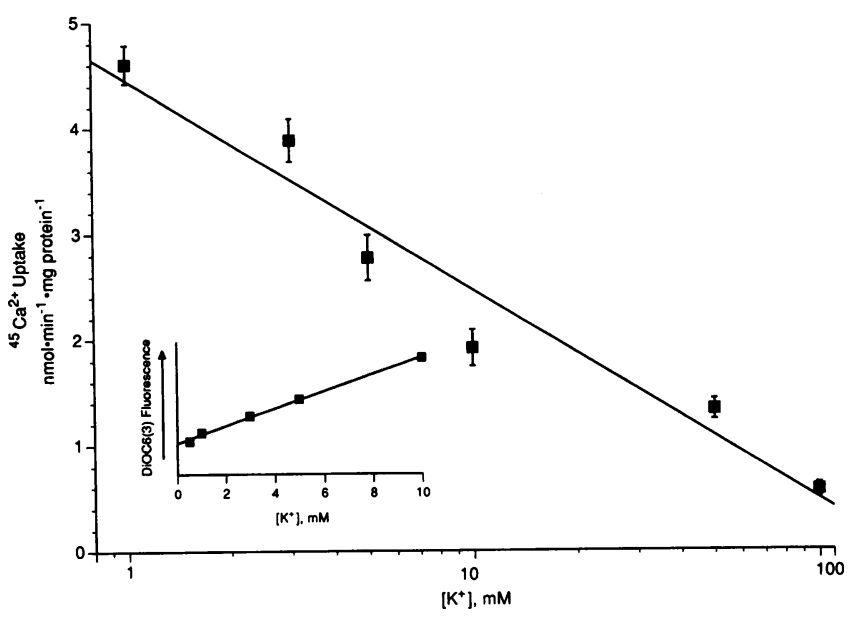

Figure 8. Effects of membrane voltage on ${ }^{45} \mathrm{Ca}^{2+}$ uptake by MDCT cells. Cellular voltage was altered by varying extracellular $\left[\mathrm{K}^{+}\right]$in the presence of $10^{-6} \mathrm{M}$ valinomycin. Reduction of the extracellular $\left[\mathrm{K}^{+}\right]$ concentration below $5 \mathrm{mM}$ increased ${ }^{45} \mathrm{Ca}^{2+}$ influx. Conversely, elevation of the extracellular potassium concentration above $5 \mathrm{mM}$ decreased ${ }^{45} \mathrm{Ca}^{2+}$ influx. The inset shows the relations between extracellular $\left[\mathrm{K}^{+}\right]$and $\operatorname{DiOC}_{6}(3)$ fluorescence, used as an index of membrane voltage, and confirms that altering extracellular $\left[\mathrm{K}^{+}\right]$had its expected effects on membrane voltage. Points represent the mean $\pm \mathrm{SE}$ of five separate experiments of triplicate determinations of ${ }^{45} \mathrm{Ca}^{2+}$ uptake.

that variations in membrane voltage can directly modulate $\mathrm{Ca}^{2+}$ entry.

If chlorothiazide-stimulated $\mathrm{Ca}^{2+}$ influx is due to changes of membrane voltage that have their origin in a decrease of the chloride diffusion potential, then replacement of extracellular $\mathrm{Cl}^{-}$should depolarize distal convoluted tubule cells thereby preventing stimulation of calcium uptake by chlorothiazide. As shown in Fig. 9, in the presence of $140 \mathrm{mM}$ extracellular $\mathrm{NaCl}$, chlorothiazide hyperpolarized MDCT cells. This effect was reversible upon removal of the drug. Isosmotic reduction of extracellular chloride to $14 \mathrm{mM}$ resulted in depolarization of membrane voltage. These results provide additional evidence for the presence of chloride channels in plasma membranes of MDCT cells. Moreover, at this reduced extracellular chloride, chlorothiazide had no demonstrable effect on membrane voltage. As expected, such membrane depolarization inhibited ${ }^{45} \mathrm{Ca}^{2+}$ uptake (Table I) and blocked the stimulatory effect of chlorothiazide noted earlier. These findings support the hypothesis that the hyperpolarization induced by chlorothiazide occurs as a result of blockade of $\mathrm{NaCl}$ cotransport with a concomitant reduction of intracellular $\mathrm{Cl}^{-}$activity. This conclusion is strengthened by the additional observations that when membrane voltage was clamped with valinomycin the stimulatory effect of chlorothiazide on ${ }^{45} \mathrm{Ca}^{2+}$ uptake was blocked, either in the presence or absence of extracellular chloride ( Table I).

If cellular chloride efflux is mediated by chloride channels, then blockade of these channels with NPPB would be expected to prevent the hyperpolarization normally induced by chlorothiazide, which in turn should inhibit ${ }^{45} \mathrm{Ca}^{2+}$ uptake stimulated by the diuretic. Fig. 10 shows that, as before, application of chlorothiazide reversibly hyperpolarized distal convoluted tubule cells. Application of NPPB $\left(10^{-5} \mathrm{M}\right)$ alone caused a slight

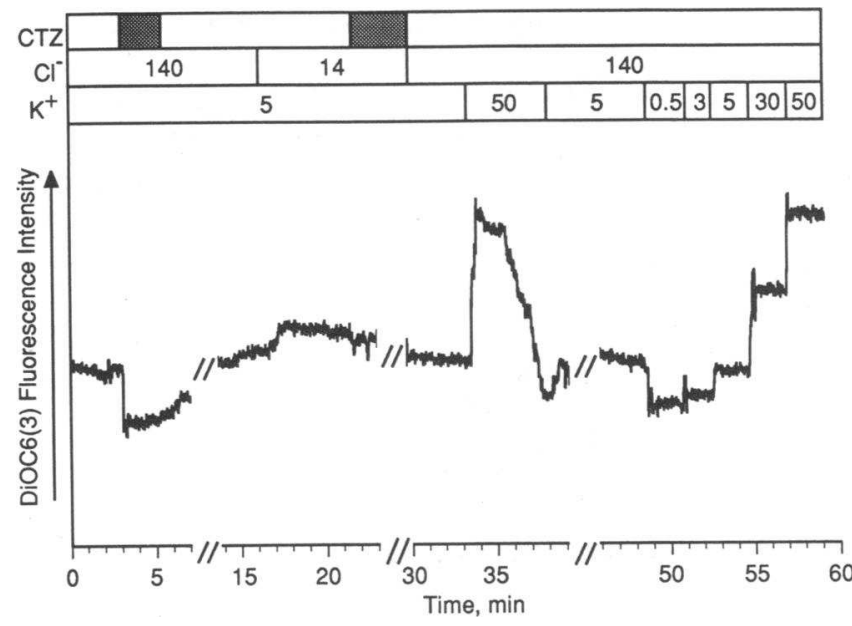

Figure 9. Effects of reduced extracellular chloride on chlorothiazideinduced membrane hyperpolarization measured with $\mathrm{DiOC}_{6}(3)$ in MDCT cells. Chlorothiazide $\left(C T Z, 10^{-4} \mathrm{M}\right)$ reversibly hyperpolarized membrane voltage as shown in Figs. 6 and 7. Exchange of incubation medium containing $14 \mathrm{mM}$ extracellular $\mathrm{Cl}^{-}$(balance gluconate) caused a modest depolarization but blocked completely the hyperpolarizing effect of a second application of CTZ. Rinsing and replacement with $140 \mathrm{mM} \mathrm{Cl}^{-}$plus $50 \mathrm{mM} \mathrm{K}^{+}$elicited a pronounced depolarization. A null-point calibration, shown on the right, was performed with graded concentrations of $\left[\mathrm{K}^{+}\right]+10^{-5} \mathrm{M}$ valinomycin. Similar effects were observed in a total of five experiments.

and transient depolarization of membrane voltage. However, the effect of subsequent addition of chlorothiazide on membrane voltage was abolished. Thus, both pharmacological blockade of chloride channels and low extracellular chloride

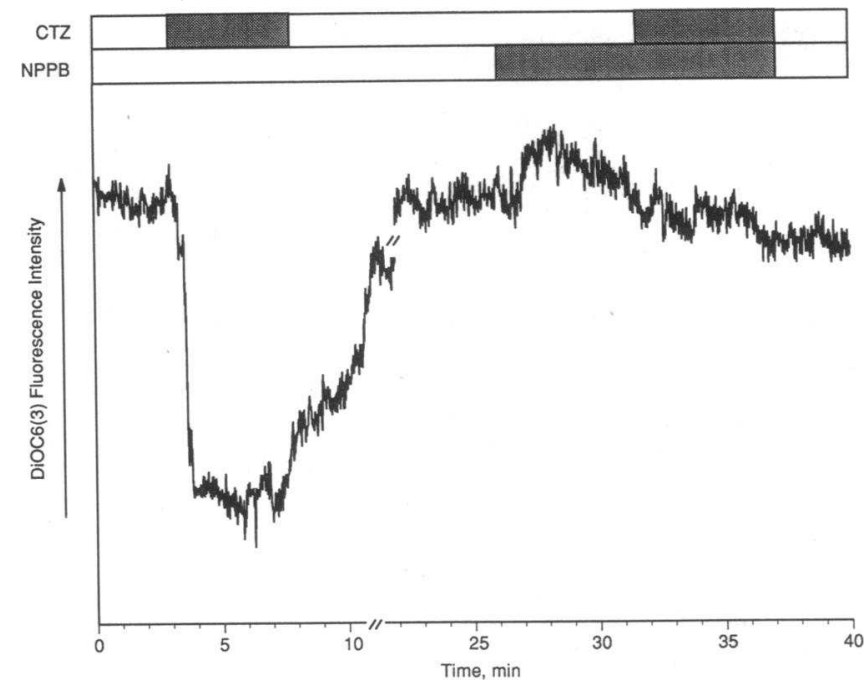

Figure 10. Effect of the chloride channel blocker NPPB on chlorothiazide-induced membrane hyperpolarization in MDCT cells. Voltage was measured with $\mathrm{DiOC}_{6}(3)$. This recording shows the hyperpolarizing effect of chlorothiazide $\left(C T Z, 10^{-4} \mathrm{M}\right)$ as the decrease of fluorescence intensity. Upon removal of $C T Z$ membrane voltage returned to control levels. Addition of the $\mathrm{Cl}^{-}$channel blocker NPPB $\left(10^{-5}\right.$ M) abolished the hyperpolarizing effect of a subsequent application of CTZ. Similar results were obtained with polythiazide in two additional experiments. 
prevent membrane hyperpolarization by chlorothiazide. We next tested the effect of NPPB on ${ }^{45} \mathrm{Ca}^{2+}$ uptake. These results are shown in Table II and demonstrate that chlorothiazidestimulated ${ }^{45} \mathrm{Ca}^{2+}$ uptake was abolished by NPPB.

Cellular mechanism of thiazide-stimulated $\mathrm{Ca}^{2}$ uptake. We recently reported that PTH stimulates $\mathrm{Ca}^{2+}$ entry through dihydropyridine-sensitive calcium channels in primary cultures of cortical thick ascending limb and distal convoluted tubule cells (16). To determine if chlorothiazide-stimulated $\mathrm{Ca}^{2+}$ entry is also mediated by dihydropyridine-sensitive channels we examined the effect of the calcium channel antagonist nifedipine $\left(10^{-5} \mathrm{M}\right)$ on chlorothiazide-stimulated ${ }^{45} \mathrm{Ca}^{2+}$ uptake and on $\left[\mathrm{Ca}^{2+}\right]_{\mathrm{i}}$. As shown in Table III, nifedipine abolished chlorothiazide-stimulated ${ }^{45} \mathrm{Ca}^{2+}$ uptake. Similarly, the rise of $\left[\mathrm{Ca}^{2+}\right]_{\mathrm{i}}$ evoked by chlorothiazide was completely blocked by nifedipine. In neither instance did nifedipine have any inhibitory action of its own. These results provide additional and direct evidence that calcium entry in distal convoluted tubule cells elicited by chlorothiazide is mediated by dihydropyridinesensitive $\mathrm{Ca}^{2+}$ channels and is stimulated by hyperpolarization.

\section{Discussion}

Under most physiological conditions, renal sodium and calcium absorption proceed in parallel. However, after certain physiological, pathophysiological, or pharmacological interventions, the absorption of calcium and sodium may be dissociated. In each of these situations the dissociation of calcium and sodium transport occurs in distal convoluted tubules or, depending on the species, the distal nephron segment responsive to PTH or sensitive to thiazide diuretics or to amiloride. The cellular mechanism of action of thiazide diuretics on $\mathrm{Na}^{+}$ absorption has been attributed to inhibition of luminal $\mathrm{NaCl}$ cotransport $(32,35)$ or to parallel $\mathrm{Na}^{+} / \mathrm{H}^{+}$and $\mathrm{Cl}^{-} / \mathrm{HCO}_{3}^{-}$ exchange (12). In contrast, the mechanism by which thiazide diuretics stimulate distal tubular $\mathrm{Ca}^{2+}$ absorption and the nature of the relations between $\mathrm{NaCl}$ absorption and $\mathrm{Ca}^{2+}$ transport have yet to be resolved.

Elucidation of the cellular mechanism responsible for the stimulation of $\mathrm{Ca}^{2+}$ absorption by thiazide diuretics has been hampered by the heterogeneity of distal tubule segments. This portion of the nephron is comprised of three morphologically and functionally distinct segments: distal convoluted tubule, connecting tubule, and initial collecting tubule (36-38). Furthermore, the short length of distal convoluted tubules $(<0.5$ $\mathrm{mm}$ ) limits direct study by microperfusion techniques. The development and application of immunodissection techniques

Table II. Effect of the Ct Channel Blocker NPPB on Chlorothiazide-stimulated ${ }^{45} \mathrm{Ca}^{2+}$ Uptake

\begin{tabular}{lcccc}
\hline & Control & CTZ & CTZ + NPPB & NPPB \\
\hline & \multicolumn{4}{c}{$n$ mol min ${ }^{-1}$ mg protein } \\
\\
${ }^{45} \mathrm{Ca}^{2+}$ uptake & $2.71 \pm 0.19$ & $3.78 \pm 0.17^{*}$ & $2.74 \pm 0.27$ & $2.58 \pm 0.16$ \\
$n$ & 8 & 8 & 6 & 8
\end{tabular}

${ }^{45} \mathrm{Ca}^{2+}$ uptake was measured as described in Methods. The final concentration of chlorothiazide (CTZ) was $10^{-4} \mathrm{M}$ and NPPB was $10^{-5}$ $M$. Values represent the mean $\pm \mathrm{SE}$ of triplicate measurements performed in $n$ separate experiments. ${ }^{*} P<0.01$ compared with control level of ${ }^{45} \mathrm{Ca}^{2+}$ uptake.
$(19,39,40)$ to the isolation and primary cell culture with subsequent cell immortalization of distal convoluted tubule cells have greatly facilitated the ability to investigate the mechanisms of $\mathrm{Na}^{+}$and $\mathrm{Ca}^{2+}$ transport. The data depicted in Figs. 1 and 3 indicate that MDCT cells express $\mathrm{NaCl}$ transport that is selectively inhibited and calcium uptake that is stimulated by chlorothiazide. These results represent a virtual signature of murine distal convoluted tubule cells. Additional preliminary evidence and further characterization of these distal convoluted tubule cells has been published (41). It should be noted that there is considerable heterogeneity of transport function in mammalian distal nephron segments. Thus, whereas PTH and thiazide diuretics exert their effects in distal convoluted tubules in mice, rats, and humans $(26,28,42)$, similar receptors and transport functions are expressed in connecting tubules in the rabbit $(43,44)$. As noted above, in the present study chlorothiazide directly stimulated ${ }^{45} \mathrm{Ca}^{2+}$ uptake and a rise of $\left[\mathrm{Ca}^{2+}\right]_{i}$. Somewhat different results were recently reported by Shimizu et al. (45). They found that PTH pretreatment of rabbit connecting tubules was necessary to elicit an effect of trichlormethiazide on calcium transport (45), but not sodium absorption (46). In our experiments, cells were grown in culture media in which the serum was heat inactivated. Further, cells were serum starved for $18 \mathrm{~h}$ before ${ }^{45} \mathrm{Ca}^{2+}$ uptake experiments or for $1 \mathrm{~h}$ before the beginning of experiments in which $\left[\mathrm{Ca}^{2+}\right]_{\mathrm{i}}$ was measured. Hence, the difference between the two studies is unlikely to stem from residual PTH activity in the incubation media we employed.

Three hypotheses have been proposed to account for thiazide-induced dissociation of sodium and calcium transport in distal nephrons. One explanation advanced by Walser (47) was that thiazide diuretics reduce the transepithelial voltage and, as a result, decrease the rate of passive calcium backflux into the tubular lumen. Two lines of evidence have since indicated that the dissociation of $\mathrm{Na}^{+}$from $\mathrm{Ca}^{2+}$ transport after administration of thiazide diuretics does not occur by such a mechanism. First, thiazide diuretics have been shown to have little, if any, effect on transepithelial voltage in mammalian distal convoluted tubules (46) and, second, the passive calcium permeability of this nephron segment is remarkably low (6). An alternative theory proposed by Costanzo and Windhager (48) suggested that the reciprocal association between sodium and calcium transport was a consequence of basolateral membrane $\mathrm{Na}^{+} / \mathrm{Ca}^{2+}$ exchange. According to this explanation, by inhibiting apical membrane sodium entry, thiazide diuretics would be expected to reduce the intracellular $\mathrm{Na}^{+}$concentration. This decrease of intracellular $\mathrm{Na}^{+}$would in turn increase the electrochemical gradient for basolateral sodium entry, thereby augmenting calcium efflux through the $\mathrm{Na}^{+} / \mathrm{Ca}^{2+}$ exchanger. Shimizu et al. (45) reported studies in which the stimulation of calcium absorption by isolated microperfused rabbit connecting tubules was thought to be mediated by increased $\mathrm{Na}^{+} / \mathrm{Ca}^{2+}$ exchange. Several lines of evidence introduced in the present study suggest that enhanced $\mathrm{Na}^{+} / \mathrm{Ca}^{2+}$ exchange is not the primary mechanism by which thiazide diuretics dissociate sodium and calcium absorption in distal convoluted tubules. The observation that chlorothiazide increased intracellular calcium activity (Figs. 4 and 5) and stimulated calcium influx (Fig. 3) in distal convoluted tubule cells is opposite to what would be predicted were $\mathrm{Na}^{+} / \mathrm{Ca}^{2+}$ exchange responsible for mediating the dissociation induced by thiazide diuretics (45).

The mechanism we propose to account for the stimulatory 
Table III. Effect of Nifedipine on Chlorothiazide-stimulated ${ }^{45} \mathrm{Ca}^{2+}$ Uptake and $\left[\mathrm{Ca}^{2+}\right]_{i}$

\begin{tabular}{|c|c|c|c|c|c|}
\hline & Control & CTZ & Nifedipine + CTZ & Nifedipine & $n$ \\
\hline${ }^{45} \mathrm{Ca}^{2+}$ uptake (nmol min $^{-1}$ mg protein ${ }^{-1}$ ) & $2.86 \pm 0.25$ & $4.15 \pm 0.24^{*}$ & $2.91 \pm 0.32$ & $2.84 \pm 0.30$ & $5-6$ \\
\hline$\left[\mathrm{Ca}^{2+}\right]_{\mathrm{i}}(n M)$ & $102 \pm 7$ & $562 \pm 8^{*}$ & $103 \pm 7$ & $99 \pm 8$ & 3 \\
\hline
\end{tabular}

${ }^{45} \mathrm{Ca}^{2+}$ uptake and $\left[\mathrm{Ca}^{2+}\right]_{\mathrm{i}}$ were measured as described in Methods. The final concentration of chlorothiazide was $10^{-4} \mathrm{M}$ and nifedipine was $10^{-5}$ M. For ${ }^{45} \mathrm{Ca}^{2+}$ uptake the values represent the mean $\pm \mathrm{SE}$ of triplicate measurements performed in the indicated number of experiments. [Ca $\left.{ }^{2+}\right]_{\mathrm{i}}$ was measured in the indicated number of experiments. ${ }^{*} P<0.01$ compared with control levels of ${ }^{45} \mathrm{Ca}^{2+}$ uptake and $\left[\mathrm{Ca}^{2+}\right]$.

action of thiazide diuretics on cellular calcium influx involves four elements: $(a)$ thiazide diuretics block apical membrane chloride entry by $\mathrm{NaCl}$ cotransport; $(b)$ continued basolateral chloride efflux through chloride channels results in a decrease of intracellular chloride activity; $(c)$ the reduction of intracellular chloride hyperpolarizes apical and basolateral cell membranes; and $(d)$ membrane hyperpolarization increases apical membrane calcium entry through dihydropyridine-sensitive calcium channels. Such a mechanism is supported by the following observations.

The first component of the proposed mechanism involves the inhibition by thiazide diuretics of coupled $\mathrm{NaCl}$ uptake. The data presented in Fig. 1 indicate that chlorothiazide inhibits sodium uptake by MDCT cells. Approximately $40 \%$ of sodium transport was inhibited by $10^{-4} \mathrm{M}$ chlorothiazide. The magnitude of this inhibition is comparable to that reported by Costanzo (7) in early distal tubules of the rat and Shimizu et al. (46) in rabbit connecting tubules, but not by Ellison et al. (8) who found that $10^{-3} \mathrm{M}$ chlorothiazide abolished $\mathrm{NaCl}$ absorption in early distal tubules of the rat. Inhibition of sodium uptake by chlorothiazide may have been incomplete in our experiments for two reasons. First, in separate experiments we found that, in addition to $\mathrm{NaCl}$ cotransport, sodium entry is mediated by amiloride-sensitive sodium channels (49). Together, these two entry mechanisms account for $\sim 88-90 \%$ of ouabain-suppressible sodium accumulation. Shimizu et al. similarly found additive inhibitory effects of trichlormethiazide and amiloride on sodium transport (46) and stimulatory effects on calcium absorption (45) in single microperfused connecting tubules. Second, chlorothiazide is a relatively weak blocker of sodium absorption (50). More potent thiazide analogs such as polythiazide, cyclothiazide, or metolazone inhibit sodium transport by an additional 5-10\%. The reason for the partial inhibition of chloride uptake (Fig. 1) by chlorothiazide may be more complicated and relate to the nature of the thiazide binding site on the cell membrane. Tran et al. (51) suggested that the $\mathrm{NaCl}$ cotransporter possesses separate binding sites for $\mathrm{Na}^{+}$and for $\mathrm{Cl}^{-}$. The $\mathrm{Cl}^{-}$binding site is shared by thiazide diuretics and by thiazide-like drugs such as metolazone. Sodium binding is thought to increase the affinity of the anion site. The binding of $\mathrm{Cl}^{-}$to the transporter permits $\mathrm{Na}^{+}$ and $\mathrm{Cl}^{-}$influx across the cell membrane. Thiazide diuretics compete with $\mathrm{Cl}^{-}$for the anion binding site on the transporter, thereby preventing the transport of $\mathrm{Na}^{+}$and $\mathrm{Cl}^{-}$. Indeed, in separate experiments we found that polythiazide inhibited ${ }^{36} \mathrm{Cl}^{-}$accumulation by $81 \pm 9 \%$ at reduced extracellular chloride concentrations ( $80 \mathrm{mM})(49)$ but only by $57 \%$ at $140 \mathrm{mM}$ chloride (unpublished observations), consistent with the prediction of Tran et al. (51).
According to the proposed mechanism, inhibition of chloride entry into MDCT cells results in a fall of intracellular chloride activity. The fact that chlorothiazide reduced intracellular chloride activity is established by experiments such as that shown in Fig. 2. Such a decrease implies first that intracellular chloride is above its electrochemical equilibrium, and second, that there is an efflux mechanism for chloride. Control intracellular chloride estimated from the Goldman-Hodgkin-Katz equation was $22 \mathrm{mM}$, clearly greater than the $10 \mathrm{mM}$ predicted from its passive distribution at the resting membrane voltage, $-72 \mathrm{mV}$. After addition of chlorothiazide, membrane voltage hyperpolarized by $20 \mathrm{mV}$. The magnitude of this hyperpolarization as assessed with the fluorescent probe, $\operatorname{DiOC}_{6}(3)$ in the present study $(20 \mathrm{mV})$ is comparable to that reported by others using conventional microelectrodes: $10-26 \mathrm{mV}(11-13,52)$. Hyperpolarization of $20 \mathrm{mV}$ to -90 to $-92 \mathrm{mV}$ would correspond to a calculated intracellular chloride activity of $5 \mathrm{mM}$. After treatment with chlorothiazide, the estimate of the actual change of intracellular chloride derived from the increase in SPQ fluorescence (Fig. 2) was $6.1 \pm 0.3 \mathrm{mM}(n=3)$. To our knowledge, these experiments represent the first demonstration that thiazide diuretics decrease intracellular chloride in mammalian renal tubular cells. However, ample precedent for such an action has been established. For instance, Stanton (12) and Duffey and Frizzell (13) showed that thiazide diuretics reduce intracellular chloride in Amphiuma distal tubules and flounder bladder, respectively. Furthermore, loop diuretics such as bumetanide or furosemide have been shown to decrease intracellular chloride in cortical thick ascending limb cells $(31,53,54)$.

The observation that the chloride channel blocker NPPB prevented the hyperpolarizing effect of chlorothiazide (Fig. 10) is consistent with the view that basolateral chloride channels mediate chloride efflux. Further, insofar as NPPB increased intracellular chloride activity and abolished the effect of chlorothiazide on intracellular chloride activity (Fig. 2), these data suggest that chloride channels, at least in part, mediate chloride efflux in MDCT cells. A basolateral chloride conductance has been reported in rabbit distal convoluted tubules (55). The observation that membrane voltage decreased to a greater extent upon a log-fold change in extracellular potassium than to an equivalent change in extracellular chloride (Fig. 9) suggests that MDCT cells also possess plasma membrane potassium channels and that, under control conditions, potassium conductance is greater than chloride conductance. The presence of plasma membrane chloride and potassium channels provides a plausible explanation for the hyperpolarization of membrane voltage induced by chlorothiazide in MDCT cells (Figs. 6 and 7 ), the third component of our model. In particular, because 
intracellular chloride is above its electrochemical equilibrium, chlorothiazide-induced blockade of chloride entry mediated by the $\mathrm{NaCl}$ cotransporter results in a decrease of intracellular chloride since it continues to leave the cell through chloride channels. The fall of intracellular chloride in turn decreases the magnitude of the chloride equilibrium potential and the cell hyperpolarizes toward the potassium equilibrium voltage. Thus, the mechanism by which thiazide diuretics inhibit $\mathrm{NaCl}$ cotransport in distal convoluted tubule cells suggested here follows explicitly the model proposed by Wittner et al. (31) for the hyperpolarization of membrane voltage and the inhibitory action of loop diuretics on $\mathrm{Na}: \mathrm{K}: 2 \mathrm{Cl}$ cotransport in thick ascending limbs.

The fourth element of the mechanism we propose for the stimulatory action of thiazide diuretics on calcium transport requires that the induced hyperpolarization increase calcium entry by distal convoluted tubule cells. The evidence in support of this contention in shown in Fig. 8 and in Tables I and II. In some respects this is the most difficult point to establish, therefore, five independent approaches were employed. First, preventing thiazide-induced hyperpolarization with the chloride channel blocker NPPB abolished the stimulatory effect of chlorothiazide on ${ }^{45} \mathrm{Ca}^{2+}$ uptake (Table II). Second, depolarizing membrane voltage by chloride replacement abolished the stimulatory action of chlorothiazide on ${ }^{45} \mathrm{Ca}^{2+}$ uptake (Table I). Third, clamping the membrane voltage with valinomycin blocked the inhibitory effect of chloride removal on ${ }^{45} \mathrm{Ca}^{2+}$ uptake (Table I). Fourth, clamping the membrane voltage with valinomycin in the presence of normal extracellular chloride blocked the stimulatory effect of chlorothiazide on ${ }^{45} \mathrm{Ca}^{2+}$ uptake (Table I). Fifth, directly manipulating the membrane voltage by varying extracellular potassium caused proportionate changes in ${ }^{45} \mathrm{Ca}^{2+}$ uptake (Fig. 8). Thus, hyperpolarizing the membrane voltage stimulated ${ }^{45} \mathrm{Ca}^{2+}$ uptake whereas depolarizing the membrane reduced it.

In previous experiments we found that calcium transport activated by PTH in primary cultures of cortical thick ascending limb plus distal convoluted tubule cells was mediated by dihydropyridine-sensitive calcium channels (16). The results of experiments shown in Table III indicate that calcium entry stimulated by chlorothiazide in MDCT cells is also mediated by dihydropyridine-sensitive calcium channels. In recent pilot experiments, we have been able to demonstrate the presence of calcium channels in apical plasma membranes of these cells (56). Further, these observations are entirely compatible with results reported by Lajeunesse et al. (15), who found that thiazide diuretics increased calcium uptake by distal tubule luminal membrane vesicles.

In summary, our results show that chlorothiazide inhibits sodium and chloride entry, stimulates calcium uptake, and increases intracellular calcium activity in immortalized MDCT cells. Inhibition of chloride entry was associated with a fall of intracellular chloride activity that resulted from continued efflux in the absence of additional chloride entry. Cellular chloride efflux was mediated by chloride channels. As intracellular chloride activity decreased, the cell membrane hyperpolarized. Membrane hyperpolarization, in turn, stimulated calcium entry. Chlorothiazide-stimulated calcium entry was mediated by dihydropyridine-inhibitable calcium channels. These results explain the mechanism by which thiazide diuretics augment calcium transport.

\section{Acknowledgments}

The excellent technical assistance of Ms. B. Coutermarsh is greatly appreciated. The authors also thank Mr. Charles Fanghella and the Nikon Corporation for support and loans of equipment.

These studies were supported by National Institutes of Health grant GM-34399. F. A. Gesek received support from National Institutes of Health grant DK-07301.

\section{References}

1. Lamberg, B.-A., and B. Kuhlback. 1959. Effect of chlorothiazide and hydrochlorothiazide on the excretion of calcium in urine. Scand. J. Clin. Lab. Invest. 11:351-357.

2. Suki, W., F. C. Rector, Jr., and D. W. Seldin. 1965. The site of action of furosemide and other sulfonamide diuretics. J. Clin. Invest. 44:1458-1469.

3. Meng, K. 1967. Mikropunktionsuntersuchungen über die saluretische wirkung von hydrochlorothiazid, acetazolamide und furosemid. NS Arch. Pharmacol. 257:355-371.

4. Kunau, R. T., Jr., D. R. Weller, and H. L. Webb. 1975. Clarification of the site of action of chlorothiazide in the rat nephron. J. Clin. Invest. 56:401-407.

5. Edwards, B. R., P. G. Baer, R. A. L. Sutton, and J. H. Dirks. 1973. Micropuncture study of diuretic effects on sodium and calcium reabsorption in the dog nephron. J. Clin. Invest. 52:2418-2427.

6. Costanzo, L. S., and E. E. Windhager. 1978. Calcium and sodium transport by the distal convoluted tubule of the rat. Am. J. Physiol. 235:F492-F506.

7. Costanzo, L. S. 1985. Localization of diuretic action in microperfused rat distal tubules: Ca and Na transport. Am. J. Physiol. 248:F527-F535.

8. Ellison, D. H., H. Velázquez, and F. S. Wright. 1987. Thiazide-sensitive sodium chloride cotransport in early distal tubule. Am. J. Physiol. 253:F546F554.

9. Costanzo, L. S., and I. M. Weiner. 1974. On the hypocalciuric action of chlorothiazide. J. Clin. Invest. 54:628-637.

10. Lavender, A. R., and T. N. Pullman. 1961. The renal effects of chlorothiazide. J. Pharmacol. Exp. Ther. 134:281-285.

11. Hansen, L. L., A. R. Schilling, and M. Wiederholt. 1981. Effect of calcium, furosemide and chlorothiazide on net volume reabsorption and basolateral membrane potential of distal tubule. Pfluegers Arch. Eur. J. Physiol. 389:121126.

12. Stanton, B. A. 1990. Cellular actions of thiazide diuretics in the distal tubule. J. Am. Soc. Nephrol. 1:832-836.

13. Duffey, M. E., and R. A. Frizzell. 1984. Flounder urinary bladder: mechanism of inhibition by hydrochlorothiazide (HCT). Fed. Proc. 43:444. (Abstr.)

14. Velázquez, H., and R. Greger. 1986. Influences on basolateral K conductance of cells of early distal convoluted tubule. Kidney Int. 29:394a. (Abstr.)

15. Lajeunesse, D., M. G. Brunette, and J. Mailloux. 1991. The hypocalciuric effect of thiazides: subcellular localization of the action. Pfluegers Arch. Eur. J. Physiol. 417:454-462.

16. Bacskai, B. J., and P. A. Friedman. 1990. Activation of latent $\mathrm{Ca}^{2+}$ channels in renal epithelial cells by parathyroid hormone. Nature (Lond.). 347:388391.

17. Bourdeau, J. E., and M. B. Burg. 1980. Effect of PTH on calcium transport across the cortical thick ascending limb of Henle's loop. Am. J. Physiol. 239:F121-F126.

18. Costanzo, L. S., and E. E. Windhager. 1980. Effects of PTH, ADH, and cyclic AMP on distal tubular Ca and Na reabsorption. Am. J. Physiol. 239:F478F485.

19. Pizzonia, J. H., F. A. Gesek, S. M. Kennedy, B. A. Coutermarsh, B. J. Bacskai, and P. A. Friedman. 1991. Immunomagnetic separation, primary culture and characterization of cortical thick ascending limb plus distal convoluted tubule cells from mouse kidney. In Vitro Cell. \& Dev. Biol. 27A:409-416.

20. Arend, L. J., J. S. Handler, J. S. Rhim, F. Gusovsky, and W. S. Spielman. 1989. Adenosine-sensitive phosphoinositide turnover in a newly established renal cell line. Am. J. Physiol. 256:F1067-F1074.

21. Gesek, F. A., and A. C. Schoolwerth. 1990. Hormonal interactions with the proximal $\mathrm{Na}^{+}-\mathrm{H}^{+}$exchanger. Am. J. Physiol. 258:F514-F521.

22. Lowry, O. H., N. J. Rosebrough, A. L. Farr, and R. J. Randall. 1951. Protein measurement with the Folin phenol reagent. J. Biol. Chem. 193:265275.

23. Grynkieiwcz, G., M. Poenie, and R. Y. Tsien. 1985. A new generation of $\mathrm{Ca}^{2+}$ indicators with greatly improved fluorescence properties. J. Biol. Chem. 260:3440-3450.

24. Zeidel, M. L., D. Kikeri, P. Silva, M. Burrowes, and B. M. Brenner. 1988. Atrial natriuretic peptides inhibit conductive sodium uptake by rabbit inner medullary collecting duct cells. J. Clin. Invest. 82:1067-1074. 
25. Verkman, A. S. 1990. Development and biological applications of chloride-sensitive fluorescent indicators. Am. J. Physiol. 259:C375-C388.

26. Brunette, M. G., D. Chabardès, M. Imbert-Teboul, A. Clique, M. Montégut, and F. Morel. 1979. Hormone-sensitive adenylate cyclase along the nephron of genetically hypophosphatemic mice. Kidney Int. 15:357-369.

27. Chabardès, D., M. Imbert-Teboul, M. Gagnon-Brunette, and F. Morel 1978. Different hormonal target sites along the mouse and rabbit nephrons. In Biochemical Nephrology. W. G. Guder, editor. Hans Huber, Bern, Switzerland. 447-454.

28. Chabardès, D., M. Gagnon-Brunette, M. Imbert-Teboul, $O$. Gontcharevskaia, M. Montégut, A. Clique, and F. Morel. 1980. Adenylate cyclase responsiveness to hormones in various portions of the human nephron. J. Clin. Invest. 65:439-448.

29. Haas, M. 1989. Properties and diversity of (Na-K-Cl) cotransporters. Annu. Rev. Physiol. 51:443-457.

30. Molony, D. A., W. B. Reeves, and T. E. Andreoli. 1989. $\mathrm{Na}^{+}: \mathrm{K}^{+}: 2 \mathrm{Cl}^{-}$ cotransport and the thick ascending limb. Kidney Int. 36:418-426.

31. Wittner, M., A. Di Stefano, P. Wangemann, and R. Greger. 1991. How do loop diuretics act? Drugs. 41 (Suppl. 3):1-13.

32. Velázquez, H., D. W. Good, and F. S. Wright. 1984. Mutual dependence of sodium and chloride absorption by renal distal tubule. Am. J. Physiol. 247:F904-F911.

33. Velázquez, H., and F. S. Wright. 1986. Effects of diuretic drugs on $\mathrm{Na}, \mathrm{Cl}$, and $\mathrm{K}$ transport by rat renal distal tubule. Am. J. Physiol. 250:F1013-F1023.

34. Verkman, A. S., R. Takla, B. Sefton, C. Basbaum, and J. H. Widdicombe. 1989. Quantitative fluorescence measurement of chloride transport mechanisms in phospholipid vesicles. Biochemistry. 28:4240-4244.

35. Stokes, J. B. 1984. Sodium chloride absorption by the urinary bladder of the winter flounder. A thiazide-sensitive, electrically neutral system. J. Clin. Invest. 74:7-16.

36. Kriz, W., and L. Bankir. 1988. A standard nomenclature for the structures of the kidney. Am. J. Physiol. 254:F1-F8.

37. Madsen, K. M., and C. C. Tisher. 1986. Structure-functional relationships along the distal nephron. Am. J. Physiol. 250:F1-F15.

38. Morel, F., and D. Chabardes. 1985. Functional segmentation of the nephron. In The Kidney: Physiology and Pathophysiology. D. W. Seldin and G. Giebisch, editors. Raven Press, New York. 519-580.

39. Smith, W. L., and A. Garcia-Perez. 1985. Immunodissection: use of monoclonal antibodies to isolate specific types of renal cells. Am. J. Physiol. 248:F1-F7.

40. Allen, M. L., A. Nakao, W. K. Sonnenburg, M. Burnatowska-Hledin, W. S. Spielman, and W. L. Smith. 1988. Immunodissection of cortical and medullary thick ascending limb cells from rabbit kidney. Am. J. Physiol. 255:F704F710.

41. Friedman, P. A., B. A. Coutermarsh, J. S. Rhim, and F. A. Gesek. 1991.
Characterization of immortalized mouse distal convoluted tubule cells. J. Am. Soc. Nephrol. 2:737. (Abstr.)

42. Morel, F. 1981. Sites of hormone action in the mammalian nephron. Am. J. Physiol. 240:F159-F164.

43. Chabardes, D., M. Imbert, A. Clique, M. Montégut, and F. Morel. 1975. PTH sensitive adenyl cyclase activity in different segments of the rabbit nephron. Pfluegers Arch. Eur. J. Physiol. 324:229-239.

44. Morel, F., D. Chabardès, and M. Imbert. 1976. Functional segmentation of the rabbit distal tubule by microdetermination of hormone-dependent adenylate cyclase activity. Kidney Int. 9:264-277.

45. Shimizu, T., M. Nakamura, K. Yoshitomi, and M. Imai. 1991. Interaction of trichlormethiazide or amiloride with PTH in stimulating calcium absorption in the rabbit connecting tubule. Am. J. Physiol. 261:F36-F43.

46. Shimizu, T., K. Yoshitomi, M. Nakamura, and M. Imai. 1988. Site and mechanism of action of trichlormethiazide in rabbit distal nephron segments perfused in vitro. J. Clin. Invest. 82:721-730.

47. Walser, M. 1971. Calcium-sodium interdependence in renal transport. In Renal Pharmacology. J. W. Fisher, editor. Appleton-Century-Crofts, New York. 21-41.

48. Costanzo, L. S., and E. E. Windhager. 1986. Transport functions of the distal convoluted tubule. In Physiology of Membrane Disorders. T. E. Andreoli, J. F. Hoffman, D. D. Fanestil, and S. G. Schultz, editors. Plenum Medical Book Company, New York. 727-750.

49. Gesek, F. A., B. A. Coutermarsh, and P. A. Friedman. 1991. Thiazide and amiloride-sensitive $\mathrm{Na}^{+}$uptake mechanisms in distal convoluted tubule cells. $J$. Am. Soc. Nephrol. 2:737. (Abstr.)

50. Friedman, P. A. 1988. Biochemistry and pharmacology of diuretics. Semin. Nephrol. 8:198-212.

51. Tran, J. M., M. A. Farrell, and D. D. Fanestil. 1990. Effect of ions on binding of the thiazide-type diuretic metolazone to kidney membrane. Am. J. Physiol. 258:F908-F915.

52. Velázquez, $\mathrm{H}$., and $\mathrm{R}$. Greger. 1985. $\mathrm{K} \& \mathrm{Cl}$ permeabilities in cells of rabbit early distal convoluted tubule. Kidney Int. 27:322. (Abstr.)

53. Salomonsson, M., E. Gonzalez, P. Westerlund, and A. E. G. Persson 1991. Chloride concentration in macula densa and cortical thick ascending limb cells. Kidney Int. 39(Suppl. 32):S51-S54.

54. Greger, R., H. Oberleithner, E. Schlatter, A. C. Cassola, and C. Weidtke. 1983. Chloride activity in cells of isolated perfused cortical thick ascending limbs of rabbit kidney. Pfluegers Arch. Eur. J. Physiol. 399:29-34.

55. Yoshitomi, K., T. Shimizu, J. Taniguchi, and M. Imai. 1989. Electrophysiological characterization of rabbit distal convoluted tubule cell. Pfluegers Arch. Eur. J. Physiol. 414:457-463.

56. Matsunaga, H., P. A. Friedman, N. Kizer, and B. A. Stanton. 1991. Calcium channels in apical membranes of distal convoluted tubule cells. J. Am. Soc. Nephrol. 2:627. (Abstr.) 